Key words: linguistic-humanitarian disciplines, linguistic-humanitarian culture, professionally oriented foreign language competence, engineer of railway transport, foreign language learning strategy, communicative competence, personality-oriented (personally developing) approach in education.

Дата надходженнястатті: 30.04.2021 p.

Рецензент: доктор педагогічних наук Козловська I. М.

\author{
УДК 37.035 \\ DOI https://doi.org/10.37915/pa.vi49.281
}

Багрій М. A.",

orcid.org/0000-0002-3506-9900

Довбенко С. Ю.,

orcid.org/0000-0003-2316-0579

\title{
ВИКОРИСТАННЯ ТВОРЧОЇ СПАДЩИНИ ІВАНА ФРАНКА В ОСВІТНЬОМУ ПРОЦЕСІ ЗАКЛАДУ ВИЩОЇ ОСВІТИ
}

Творча спадщина Івана Франка з кожним роком усе більще привертае увагу наукової, педагогічної і громадської спільноти як у нашій країні, так $i$ за кордоном. Гуманістична педагогічна система, розроблена видатним діячем вітчизняної освіти, вирізняеться новаторськими ідеями $і$ положеннями, які й сьогодні примножують теорію і практику освіти та виховання. Фундаментальність спадщини Франка надихає не одне покоління як науковців, так $i$ педагогів-практиків, проте залишається чимало питань щодо впровадження його прогресивних ідей у практику сучасних закладів вищої освіти.

Доцільність концепції навчання протягом усього життя $i$ сама ідея неперервного навчання, яка завжди була присутня в масовій свідомості, - це кроки в напрямку все більшого утвердження цієеї ідё̈ в суспільстві, зроблені педагогами-новаторами свого часу впродовж довгих років історії розвитку освіти. Педагогічні ідеї та творча спадщина Івана Франка не втрачають своєї актуальності і сьогодні, залишаючись напрочуд сучасними та своєчасними. Ідеї видатного науковия щодо організації процесу освіти в різних ї̈ ланках відповідно до принцииу неперервності є особливо значущими в умовах реформування системи освіти в Украйні. Безперечно, вони користуються особливим запитом у сучасному інформаційнокомунікаційному просторі, інтегровані в концепцію навчання протягом усього життя.

Творчість Франка як педагогічна енц̧иклопедія для сучасного педагога розкриватиме нові сторінки осмислення сучасних освітніх проблем. Теоретичні узагальнення письменника покладено сьогодні у фундамент особистісно орієнтованого підходу до навчання й виховання у всіх ланках освіти. Організаційно-педагогічні умови успішної роботи з дітьми різних вікових категорій, сформульовані талановитим педагогом, є актуальними $і$ донині. Зауважимо, щобоуло б упущенням залишати досвід видатного педагога, вченого, практика, не використовуючи съогодні ключових понять його системи та не враховуючи сутності й основ етики освіти та навчання, визначаючи їх як актуальні та своєчасні лище для освітньої системи минулого століттял.

Ключові слова: Іван Франко, творча спадщина, вища освіта, педагогіка, навчання, виховання.

Постановка проблеми. Вагомий унесок І. Франка у вивчення історії української та європейської освіти, у розвиток теорії виховання і навчання, а також столітня традиція осмислення цієї спадщини дають змогу говорити про формування

*C Багрій M. A.

*C Довбенко С. Ю.

जos 251 
педагогічної франкіани як окремого напряму української педагогічної думки та франкознавства. Тому метою статті $є$ аналіз творчої спадщини Івана Франка і акцентуація на продуктивному досвіді історіографічного аналізу педагогічної франкіани та з'ясуванні основних тенденцій і здобутків іiі розвитку для впровадження в освітній процес закладу вищої школи.

Аналіз досліджень. У науковій літературі представлено поглиблений аналіз поглядів І. Франка на розвиток дошкільного виховання (Ю. Ступак), початкової освіти (I. Зайченко), морального (С. Чавдаров), трудового (Н. Каленіченко), естетичного (П. Яременко) виховання; Франкові рефлексії образу вчителя (К. Бориславський, М. Походзіло, В.Смаль); унесок письменника у розвиток дитячої літератури (Є. Городецька, Л. Маляренко, Г. Паперна); його погдяди на навчання і виховання (В. Городівський, В. Аесин), інші аспекти розвитку особистості (Г. Васянович, М. Година, Т. Пантюк, Г. Пурель, В. Святовець, Н. Слюсаренко, С. Суховський та ін.).

Аналіз репрезентативних студій з означеної проблеми дає змогу стверджування, що, попри ідейну заідеологізованість, вони заклади основи і визначиди годовні контури педагогічної франкіани. Багато з них до сьогодні не втратили наукового і пізнавального значення, тому мають не ігноруватися, а предметно вивчатися й використовуватися сучасними науковцями.

Означені праці та зростаючий масив статейних й інших публікацій відображають важдиві тенденції розвитку сучасної педагогічної франкіани України щодо нарощування, розширення іï тематичного спектру та актуалізації педагогічних ідей письменника в руслі розв'язання назрілих завдань реформування системи освіти, удосконалення теорії і методики виховання і навчання учнівської та студентської молоді, підвищення статусу педагога тощо.

Своє продовження і розвиток знайшла ініційована за радянського періоду тенденція щодо вивчення й апробації творчої спадщини І. Франка у річищі підготовки навчально-методичного забезпечення курсу української літератури в загальноосвітній середній школі та закладі вищої освіти. Таким промовистим прикладом стадо відновлення заходами науково-педагогічних працівників Дрогобицького державного педагогічного університету імені Івана Франка започаткованої 1957 р. підготовки науково-методичних збірників «Іван Франко в школі» $(2003,2009)$ [3-5]. Уміщені в них змістовні матеріали орієнтовані на теоретичне обгрунтування окремих аспектів Франкової педагогічної концептосфери (щодо викладання української літератури; формування національної свідомості; удосконалення морального і національнопатріотичного виховання тощо) та їхне спрямування у практичне русло узмістовлення освітнього процесу.

Виклад основного матеріалу. У світовій культурі і науці загалом, а в радянській і пострадянській особливо, утвердилася об'єктивно зумовлена традиція щодо актуалізації творчості знаних громадських діячів i вчених 3 нагоди ювілейних дат життедіядьності. Вона дозволяе відстежувати загальний розвиток франкознавства та виокремлення і посилення його педагогічного струменя. У такому кдючі, поряд із представницькими франкознавчими конгресами 1956, 1996 рр., іншими подібними зібраннями, виокремлюємо влаштований за традицією у Аьвівському національному університеті імені Івана Франка Міжнародний науковий конгрес 2006 р., на якому вперше в історії таких форумів створили окрему секцію «Педагогіка». Представлені на ньому матеріали загалом відображають означенні тенденції розвитку педагогічної франкіани та, що не менш важдиво, утверджують іiі статус як окремого напряму франкознавства.

Яскравим свідченням цього i виявом розширення тематичного спектру педагогічної франкіани слугуе спеціальний випуск історико-педагогічного альманаху Житомирського державного університету імені Івана Франка «Педагогічні ідеї Івана Франка в освіті сьогодення» (2016) [9]. Уміщені в ньому бдизько сотні матеріалів

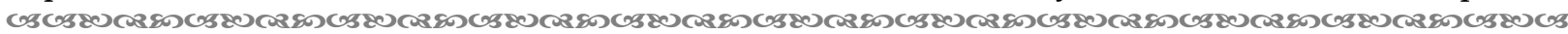
252 
розподілені за трьома основними розділами, що стосуються життя і педагогічної діяльності І. Франка, його виховних ідей, осучаснення освітньої рецепції вченого в освітньому просторі України. Вони мають різний науковий рівень i не завжди відзначаються новизною, однак засвідчують універсальність і невичерпність потенціалу творчого генія Франка, що спонукає генерувати нові ідеї й інновації для вдосконалення освітнього процесу.

Попри потужний розвиток педагогічної франкіани, іiї вузьким місцем залишається застосування зарубіжного досвіду франкознавства. Між тим, його використання, як, приміром, свідчить виданий ще 1957 р. науковцями діаспори збірник «І. Франко й франкіяна на Заході» (Вінніпег, 1957) [2], може бути доволі продуктивним і актуальним у контексті інтеграції України в европейський освітній простір.

Означені тенденції, риси, характеристики розвитку педагогічної франкіани тією чи іншою мірою притаманні історіографії про педагогічні персоналії інших західноукраїнських письменників, зокрема тих, яких відносять до кдасиків української літератури.

Реферовані студії відображають загадьну тенденцію щодо міждисципдінарного осмислення педагогічних ідей письменників на основі їхніх різножанрових творів та джерел особового походження. Зважаючи на значну кількість педагогічних персоналій літераторів, що перебувають у предметному полі дослідження, та нагромадження значного масиву різнопрофільних студій, уважаємо за доцільне зосередитися на їхньому синтезованому структуровано-реферативному огляді та визначенні основних рис і тенденцій розвитку історіографії досліджуваної проблеми.

До з'ясування цієї проблеми треба підходити крізь вимір широкого міждисциплінарного концептуально-методологічного дискурсу, зокрема, діалогу між історико-педагогічною наукою та дітературною творчістю, що передбачає виявлення чинних між ними ліній перетинання та врахування їхніх гносеологічних відмінностей.

3 одного боку, з онтологічних позицій вони представдяють дві різні форми (способи, підходи) пізнання освітньо-педагогічної дійсності. Перша науковораціональна виявляеться в оперуванні формалізованими поняттями, категоріями, аналітичними методами і прийомами, які продукують логічні уявлення, судження, висновки, які обгрунтовуються предметним науковим аналізом. Друга форма стосується ірраціонально-чуттевим сприйняттям світу і його опису. Вона наскрізь суб'єктивна й зумовлена особистісним внутрішнім світом письменника, який у рефлексії реалій буття не зобов'язаний дотримуватися чіткої логіки, не має прагнути до ії точного, об'єктивного відтворення, тому в своєму художньому осмисленні може припускатися домислу і вимислу.

3 іншого боку, між історико-педагогічною наукою та дітературною творчістю є спільне онтологічне начало. Перша, як і будь-яке інше гуманітарне знання, містить поряд із дискурсно-логічним (описово-аналітичним) й інтуїтивно-образний складник. Вона виразно виявляеться в їі аксіологічному вимірі, адже цінності загальнолюдські (добро, честь, совість, справеддивість, почуття прекрасного тощо) та націонадьні (моральність, жертовність, терпимість, доброзичливість, релігійність, працелюбність, сім'я та ін.) є апріорі ірраціональними за своєю природою. В історико-педагогічній, на відміну від точних наук, відсутній жорсткий алгоритм дослідження.

Отож у педагогічної науки та дітературної творчості є спільний стрижень людина як основний предмет дослідження. Саме їй (людині) Франко приділяв найбільше уваги. Формування людини в усьому розмаїтті проявів цього процесу стало предметом осмислення і відображення в художній дітературі задовго до появи відповідних психолого-педагогічних теорій. А феномен виховання сягає коріннями сивої давнини, коли не було ні першого, ні другого, тож саме він слугуе онтологічним фундаментом для 3'ясування точок дотику історико-педагогічної науки і дітературної творчості. Поєднуючи в собі пізнавальне і ціннісне ставлення людини до світу,

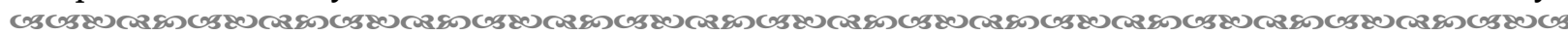
253 
дітературні твори передають ऑiі цілісне світобачення, відображають естетичне сприйняття педагогічних реалій у художніх образах. Тому вчені закономірно ставлять питання про «педагогічну свідомість письменників», адже їхні твори виконують «учительську роль», дидактичні функції, що виявляються в потужному впливі на освіту і виховання особистості $[8$, с. 8-10].

У такому сенсі, згідно з влучним висловом Б. Неменського, у педагогіці, як і в людському мисленні, є «два крила»: одне - це науково-теоретичне і раціональнологічне мислення, друге - це художнє, емоційно-образне. На одному 3 них вона не зможе піднятися, адже буде, як «підбита птаха» [7, с. 42-43]. Ця образна алегорія увиразнює тісний зв' язок історико-педагогічної науки, яка намагається розкрити тривкі взаємозв'язки і закономірності освітньо-педагогічного процесу головно шияхом абстрактного образного мислення, 3 одного боку, та художньою літературою, яка в образній формі прагне відобразити освітньо-педагогічну дійсність, з іншого. В обох випадках бачимо стремління до цілісного осмислення внутрішнього світу особистості як неповторної унікальності та типізації освітніх явищ, педагогічних ситуацій, громадсько-просвітницької діяльності та їхніх основних суб'єктів - учителів і учнів, батьків і дітей, культурних діячів тощо.

Забезпечуючи культурологічну глибину осмислення педагогічних проблем, художня модель виховання розкриває різнобічну сутнісну картину процесу становлення особистості дитини, набуває характеру теоретичного аналізу, адже дозволяе досліджувати закономірності процесу їі формування і становлення в аспектах глобального співвідношення Дюдини, Природи і Суспільства.

Означені положення і підходи дають можливість зробити важливі проміжні висновки, крізь призму яких проєктуємо подальший розгдяд інформативного значення й інші характеристики означених складників джерельної бази дослідження. По-перше, художню дітературу Івана Франка слід визнати важдивим і своєрідним різновидом педагогічних та історико-педагогічних джерел, адже ії твори мають соціально-виховне значення, естетично відображають і водночас формують свідомість, ментальність, поведінку особистості. Це виявляється і забезпечується їхньою значущою функційністю щодо нагромадження, збереження та передачі від одного покодіння до іншого моральних, соціальних і національних цінностей, що відображають світобачення, ідеали і прагнення всього народу й окремих соціальних груп.

По-друге, художні твори як складник соціокультурного простору певної епохи природно і всебічно передають іiі дух, смаки, цінності, що дає важливе підгрунтя для глибокого розуміння освітньо-педагогічного процесу та властивих йому норм поведінки, виявів свідомості, суспільних зв'язків, міжособистісних стосунків та інтересів, прагнень тощо. По-третє, співставлення представлених історико-педагогічною наукою та різними жанрами літератури моделей освітньо-педагогічних відносин і особистісних образів дає привід для їхнього розгляду та використання як своєрідного інформативно насиченого джерела і засобу осмислення окремих ідей щодо вдосконалення процесу виховання і навчання та розвитку педагогічної думки загалом.

Варто визнати, що за радянського періоду, попри ідейну ангажованість у відборі письменників і їхніх творів, було закладено важливий фундамент щодо систематизації та оприлюднення доробку класика української літератури Івана Франка, який до сьогодні залишається важдивим джерелом його пізнання та наукового аналізу.

Різножанрові художні твори Івана Франка органічно доповнюють зараховані в другу групу джерела особового походження. Поширений у науці підхід, згідно з яким вони ототожнюються з мемуаристикою (фр. memoires - спогад, згадка), є прийнятним, якщо сюди віднести такі его-джерела, як спогади, автобіографії, епістолярій (дистування), щоденники. Важко погодитися 3 вкдюченням до них портретів і некрологів, які мають інше походження та інформаційне навантаження. 3 одного боку, вони дають унікальну інформацію, яку не можна почерпнути з інших документів про

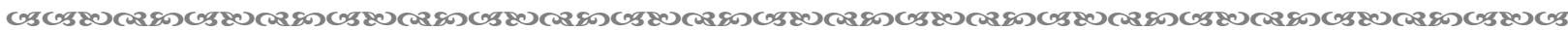
254 
життедіяльність митця. 3 іншого, зважаючи на те, що багато його художніх творів мають автобіографічний характер, ці джерела набувають особливого значення для їхнього аналізу, адже в поглядах, учинках, діях дітературних героїв часто проглядаються біографічні сюжети та педагогічні ідеї, рефлексії самих авторів (чотири публікації Франкової автобіографій представлені у збірці Ю. Ауцького [6]).

У контексті досліджуваної проблеми не втрачає методологічної актуальності зауваження I. Франка щодо жанру біографії. Він стверджував, що є «письменники, чий життєпис цікавіший від їхніх творів», адже вони $є$ «представниками того часу, коди жили», тому їхні життеписи дають змогу «увійти в таємниці духу... доби, бо саме в них... знаходить своє найвиразніше втілення» [10, с. 28].

Висновки. Отже, аналіз творчого доробку Івана Франка дає змогу стверджувати, що використання творчої спадщини митця в освітньому процесі закладу вищої освіти є значущою для розвитку педагогічної науки та освіти України проблемою. Важдива фактографічна основа для цього створюе нагромаджену і систематизовану в процесі пошуково-евристичної роботи джерельну базу у вигляді різножанрових творів Франка. Таким чином, аналіз творчості письменника дає змогу узагальнити, що впровадження творів Франка в практику роботи закладу вищої освіти потребуе широкого використання різноманітних форм виховної діяльності, взаємозв'язку змісту і методів діяльності викладачів. Це і становить перспективу подальшого наукового пошуку.

\section{Список використаних джерел:}

1. Багрій М. А. Педагогічна ідеї і просвітницька діядьність українських письменників Західної України (кінець XVIII 30-ті роки XX сторіччя): монографія / за заг. ред. д. п. н., проф. Г. Білавич. Івано-Франківськ: НАIP, 2020. 578 с.

2. I. Франко й франкіяна на Заході: статті й матеріяли (3 приводу століття народин 1856-1956) / за ред. Яр. Рудницького. Українська Вільна Академія Наук. Збірник Заходознавства. T. IV (2). Вінніпег, 1957. 231 с.

3. Іван Франко в школі. Збірник матеріалів виїзного засідання відділу методики хітератури НДІП УРСР, присвяченого 100-річчю з дня народження І. Я. Франка. Дрогобич, 1957. 188 с.

4. Іван Франко в школі: збірник науково-методичних праць / ред. кол.: М. Гуняк (гол. ред.), А. Гулевич, О. Баган та ін. Вип. 1. Дрогобич: Коло, 2003. 260 с.

5. Іван Франко в школі: збірник науково-методичних праць / ред. кол.: А. Гулевич (гол. ред.), Є. Пшеничний, 3. Гузар та ін. Вип. 2. Дрогобич: Коло, 2009. 257 с.

6. Ауцький Ю. Самі про себе. Автобіографії видатних українців XIX ст. / за ред. Ю. Ауцького. Нью-Йорк: Видання Вільної Академії Наук у США, 1989. 378 с.

7. Неменский Б. М. Позаурочные формы работы. Советская педагогика. 1991. № 9. С. 41-45.

8. Роботова А.С. Художественно-образное познание педагогической действительности средствами литературы: автореф. дисс. ... д-ра пед. наук: 13.00.01. Санкт-Петербург, 1996. $38 \mathrm{c}$.

9. Франко І. Теорія і розвій історії літератури. Зібрання творів у 50 m. Т. 40. Київ: Наукова думка, 1976. C. 114-120.

10. Франко І. Я. Давні акти до нового спору. Зібрання творів у 50-и томах. Київ: Наукова думка, 1985. Т. 46. Ч. 1. С. 347-351.

\section{References:}

1. Bahrii, M. A. (2020). Pedahohichna idei i prosvitnytska diialnist ukrainskykh pysmennykiv Zakhidnoi Ukrainy (kinets XVIII 30-ti roky XX storichchia) [Pedagogical ideas and educational activities of Ukrainian writers of Western Ukraine (late XVIII 30-ies of the twentieth century)]. IvanoFrankivsk: NAIR [in Ukrainian].

2. Rudnytskoho, Yar. (Ed.). (1957). I. Franko y frankiyana na Zakhodi. Statti y materiyaly (z pryvodu stolittya narodyn 1856-1956) [I. Franko and the Franconian in the West: articles and materials (on the centenary of the peoples of 1856-1956)]. Ukrainska Vilna Akademiia Nauk. Zbirnyk Zakhodoznavstva, IV (2), 231 [in Ukrainian]. 
3. Ivan Franko $v$ shkoli [Ivan Franko at school]. (1957). Zbirnyk materialiv vyiznoho zasidannia viddilu metodyky literatury NDIP URSR. Prysviachenoho 100-richchiu z dnia narodzhennia I. Ya. Franka [Collection of materials of the field meeting of the department of literature methodology of the Research Institute of Literature of the Ukrainian SSR. Dedicated to the 100th anniversary of Ivan Franko's birth]. Drohobych [in Ukrainian].

4. Huniak, M., Hulevych, L., \& Bahan, O. (2003). Ivan Franko v shkoli. Zbirnyk naukovo-metodychnykh prats [Ivan Franko at school. Collection of scientific and methodical works]. Drohobych: Kolo [in Ukrainian].

5. Hulevych, L., Pshenychnyi, Ye., \& Huzar, Z. (Ed.). (2009). Ivan Franko v shkoli. Zbirnyk naukovometodychnykh prats [Ivan Franko at school. Collection of scientific and methodical works]. Drohobych: Kolo [in Ukrainian].

6. Lutskyi, Yu. (Ed.). (1989). Sami pro sebe. Avtobiohrafii vydatnykh ukraintsiv XIX st. [About themselves. Autobiographies of prominent Ukrainians of the XIX century]. New York: Publication of the Free Academy of Sciences in the United States [in Ukrainian].

7. Nemenskii, B. M. (1991). Pozaurochnye formy raboty [Extracurricular forms of work]. Sovetskaia pedagogika, 9, 41-45 [in Russian].

8. Robotova, A.S. (1996). Khudozhestvenno-obraznoe poznanie pedagogicheskoi deistvitelnosti sredstvami literatury [Artistic and figurative cognition of pedagogical reality by means of literature]. (Extended abstract of Doctor's thesis). Sankt-Peterburg [in Russian].

9. Franko, I. Ya. (1976). Teoriya i rozviy istoriyi literatury. In Zibrannya tvoriv u $50 t$. [Theory and development of the history of literature. Collected works in 50 volumes]. (Vol. 40). Kyiv: Naukova Dumka [in Ukrainian].

10. Franko, I. Ya. (1985). Davni akty do novoho sporu. In Zibrannya tvoriv u 50-y tomakh [Ancient acts to the new dispute. Collected works in 50 volumes]. (Vol. 3, Part 1). Kyiv: Naukova Dumka [in Ukrainian].

Bagriy M. A., orcid.org/0000-0002-3506-9900

Dovbenko S. Yu., orcid.org/0000-0003-2316-0579

\section{USE OF IVAN FRANKO'S CREATIVE HERITAGE}

IN THE EDUCATIONAL PROCESS OF THE HIGHER EDUCATION INSTITUTION

Ivan Franko creative heritage attracts more and more attention of the scientific, pedagogical and public community both in our country and abroad. The humanistic pedagogical system, developed by a prominent figure in national education, is characterized by innovative ideas and provisions that still multiply the theory and practice of education and upbringing. The fundamentality of Franko's legacy inspires more than one generation of both scholars and educators, but many questions remain about the implementation of his progressive ideas in the practice of modern higher education institutions.

The expediency of the concept of lifelong learning and the very idea of lifelong learning, which has always been present in the mass consciousness - these are steps towards the growing assertion of this idea in society made by educators-innovators of their time during the long history of education. Ivan Franko pedagogical ideas and creative heritage do not lose their relevance today, remaining surprisingly modern and timely. The ideas of an outstanding scientist on the organization of the educational process in its various parts in accordance with the principle of continuity, are especially important in the context of reforming the education system in Ukraine. Undoubtedly, they are in special demand in the modern information and communication space, integrated into the concept of lifelong learning.

Franko's work at a pedagogical encyclopedia for a modern teacher will open new pages of understanding modern educational problems. Theoretical generalizations of the writer are laid today in the foundation of a person-centered approach to teaching and education at all levels of education. Organizational and pedagogical conditions for successful work with children of different ages, formulated by a talented teacher, are still relevant today. Note that it would be an omission to leave the experience of an outstanding teacher, scientist, practice without using today the key concepts 
of his system and without considering the essence and foundations of ethics of education and training, defining them as relevant and timely only for the educational system of the last century.

Key words: Ivan Franko, creative heritage, higher education, pedagogy, education.

Дата надходження статті: 27.04.2021 p.

Рецензент: доктор педагогічних наук, професор Білавич Г. В.

УДК 37.091.113:378.046-021.68(477)

DOI https://doi.org/10.37915/pa.vi49.283

Вишневська Я. А. ,

orcid.org/0000-0003-3703-4119

\section{РЕТРОСПЕКТИВНИЙ АНАЛІЗ ІСТОРИКО-ПЕДАГОГІЧНИХ ПЕРЕДУМОВ РОЗВИТКУ ПІСЛЯДИПЛОМНОЇ ОСВІТИ КЕРІВНИХ ПЕДАГОГІЧНИХ КАДРІВ УКРАЇНИ}

У статті досліджено історико-педагогічні передумови становлення системи післядипломної освіти керівників закладів освіти у період першої половини ХХ сторіччя. У контексті послідовних перетворень у системі післядипломної педагогічної освіти розкрито особливості історичного періоду периої половини ХХсторіччя, в якому відбувалось формування національної системи післядипломної педагогічної освіти, зокрема зароджувались процеси, пов'язані з підвищення квахіфікації керівних педагогічних кадрів. Обьрунтовано, що процес розвитку післядипломної освіти керівних педагогічних кадрів нерозривно пов' язаний iз розвитком всієї системи післядипломної педагогічної освіти та є наслідком історичного усвідомлення важливості ролі ефективного управління закладом освіти у підвищенні якості освітнво-виховного процесу. На прикладі переписів працівників освіти, що проводились у 1929-1933 роках, надано характеристику кількісному та якісному складу педагогічних працівників, у тому числі наведено рівень професійної підготовки керівних педагогічних кадрів до управління закладами освіти. Охарактеризовані основні форми підвищення кваліфікації педагогічних кадрів у першій половині ХХ сторіччя, серед яких як таку, що мала особливе значення для професійний розвитку керівників шкіл, виокремлено заочну педагогічну освіту, зописом напрямів за якими здійснювалась підготовка. Зроблено висновок, що питання необхідності у запровадженні ефективного управління закладом освіти виникло як реакція на поступові політичні, соціальні та культурні зміни в украйнському суспільстві та державі, що поглиблювали проблеми розвитку всієї освітньої галузі. А наукове переосмислення в середині ХХ сторіччя провідної ролі ефективного управління закладом освіти та професіоналізму керівника стає передумовою виокремлення із загальної системи післядипломної педагогічної освіти важливої ї̈ підсистеми, що мала на меті постійне професійне зростання керівних педагогічних кадрів.

Ключові слова: курси підвищення квалібікації, керівні й педагогічні кадри, програма курсів, форма і зміст.

Постановка проблеми. Перебудова системи загальної середньої освіти України вимагає пошуку нових шляхів адміністрування роботи закладів загальної середньої освіти, від ефективності якого залежить надання якісної сучасної освіти.

Досягнення визначених реформою «Нової української школи» цілей неможливе без забезпечення закладів загальної середньої освіти професійно підготовленими, ініціативними, прогресивними керівниками, здатними до запровадження змін. Зазначене закономірно зумовлюе потребу в розвитку професійних компетентностей, необхідних керівнику для організації ефективного управління закладом освіти.

*C) Вишневська Я. А.

U3 